\title{
Rancang Bangun Infuse Fluida Detector untuk Pasien ICU menggunakan Metode WSN (Wireless Sensor Network)
}

\author{
Robi Yusuf Habibie ${ }^{1}$, Andi Adriansyah ${ }^{2}$ \\ ${ }_{1,2}^{1}$ Teknik Elektro, Universitas Mercu Buana, Jakarta, Indonesia \\ ${ }^{1}$ robiyusuf1@gmail.com* \\ *corresponding author
}

\begin{tabular}{|c|c|}
\hline ABSTRACT & Article Info \\
\hline $\begin{array}{l}\text { ICU (Intensive Care Unit) patients really need more attention in their care } \\
\text { because usually these patients suffer from serious illnesses. In handling it must } \\
\text { also pay attention to the administration of fluids in the form of infusions that } \\
\text { must be controlled according to the doctor's directions. Therefore, this study } \\
\text { will discuss the infusion method detection system for ICU patients using the } \\
X K C-Y 26-P N P \text { sensor with wireless communication using a Wi-Fi network and } \\
\text { sending notifications via a telegram application that can be accessed by the } \\
\text { room nurse or patient waiting so that later they can remind them. to the room } \\
\text { nurse if the fluid has not been replaced. This study aims to develop a fall } \\
\text { detection device with the NodeMCU ESP82666 controller, which will then be } \\
\text { sent a notification via Telegram. The study concluded that this device can detect } \\
\text { the presence of fluid in the infusion bottle accurately if the infusion bottle is } \\
\text { empty, the main processor will immediately send a notification to the Telegram } \\
\text { Bot that has been created and sound a buzzer as a reminder to replace the } \\
\text { infusion fluid by the practitioner as soon as possible. }\end{array}$ & $\begin{array}{r}\text { Keywords: } \\
\text { Arduino IDE, } \\
\text { XKC-Y26-PNP, } \\
\text { Infuse Detector, } \\
\text { NodeMCU ESP8266, } \\
\text { Telegram. }\end{array}$ \\
\hline \multicolumn{2}{|l|}{ ABSTRAK } \\
\hline $\begin{array}{l}\text { Pasien ICU (Intensive Care Unit) sangat membutuhkan perhatian lebih dalam } \\
\text { perawatannya karena biasanya pasien tersebut menderita penyakit yang cukup } \\
\text { serius. Dalam penanganannya harus pula diperhatikan pemberian cairan berupa } \\
\text { infus yang harus dikontrol sesuai dengan arahan dokter. Oleh karena itu } \\
\text { penelitian ini akan membahas mengenai sistem pendeteksi caran infus untuk } \\
\text { pasien ICU menggunakan sensor XKC-Y26-PNP dengan komunikasi secara } \\
\text { wireless memanfaatkan jaringan Wi-Fi dan mengirimkan notifikasi pada } \\
\text { telegram yang dapat diakses oleh perawat ruangan atau penunggu pasien agar } \\
\text { nantinya dapat mengingatkan kepada perawat ruangan apabila cairan belum } \\
\text { diganti. Penelitian ini bertujuan untuk mengembangkan perangkat pendeteksi } \\
\text { jatuh dengan kendali NodeMCU ESP82666 selanjutnya akan dikirim notifikasi } \\
\text { melalui Telegram. Penelitian menyimpulkan bahwa perangkat ini dapat } \\
\text { mendeteksi keberadaan cairan pada botol infus secara akurat apabila cairan } \\
\text { botol infus kosong maka main prosesor akan segera mengirimkan notifikasi } \\
\text { pada Bot Telegram yang sudah dibuat dan membunyikan buzzer sebagai } \\
\text { pengingat agar cairan infus diganti oleh praktisi segera mungkin. }\end{array}$ & \\
\hline
\end{tabular}




\section{PENDAHULUAN}

Pasien ICU (Intensive Care Unit) adalah pasien yang membutuhkan perawatan khusus. Departemen yang menangani hal tersebut adalah unit khusus yang dikelola untuk merawat pasien sakit berat dan kritis, cedera dengan penyulit yang mengancam serta melibatkan tenaga kesehatan terlatih, didukung dengan kelengkapan peralatan medis khusus. Tidak sembarang pasien dapat langsung dimasukkan ke dalam ruang ICU dan tak sembarang juga pasien dapat meninggalkan ICU, semuanya berdasarkan pada prosedur yang berlaku dan menjadi hal yang sangat diperhatikan. Berhubungan dengan tenaga kesehatan yang terlatih, pelayanan medis menjadi aspek yang sangat vital bahkan dari yang terkecil sekalipun, seperti mengganti cairan infus yang habis tanpa mengenal waktu (Hammad et al., 2018).

Sayangnya masih saja terjadi keterlambatan penggantian cairan infus pada pasien, karena minimnya informasi yang diberikan oleh peralatan yang berhubungan dengan cairan infus tersebut. Hal tersebut akan mengakibatkan kurangnya cairan pada tubuh pasien dan dapat diindikasi pada gejala seperti dehidrasi maupun bibir pecah-pecah, lesu dan lain sebagainya. Oleh karenanya informasi yang mumpuni dibutuhkan guna menghindari hal yang dapat merugikan dan berbahaya dari segi pasien maupun petugas medis (Widiawati et al., 2017).

Pada penelitian sebelumnya di Seminar Nasional Terapan Riset Inovatif (SENTRINOV) Ke-6 oleh M. Yoga Firdaus, A. Shahib Al Banna, Annur Thariq Saputra dan Nurmahaludin mencoba membuat sistem kontrol dan monitoring cairan infus yang dilengkapi dengan monitoring level berbasis NodeMCU sistem yang digunakan adalah dengan memonitor kondisi berat infus yang diamati menggunakan sensor load-cell yang terhubung dengan NodeMCU. Dari hasil pengujian diperoleh data bahwa infus dalam kondisi hampir habis jika berat kurang dari 200 gram. Sedangkan laju tetes infus normal (20 tetes/menit) diperoleh jika sudut motor servo 24-26 derajat (Firdaus et al., 2020).

Sedangkan pada Jurnal SIMETRIS, Vol. 11 No. 1 oleh Kristina Natalia Tunga Yayer, Widya Andyardja Weliamto, Ph.D., Ir. Rasional Sitepu, M.Eng dan Hartono Pranjoto, Ph.D. dikembangkan lagi monitoring dan penghentian cairan infus menggunakan timbangan infus digital dengan memanfaatkan web server. sistem yang digunakan pada alat ini adalah dengan diberi pengaman agar dapat menghentikan aliran cairan infus yang mengalir ke pembuluh vena ketika cairan infus akan habis. Data dari banyak cairan infus yang tersisa dan ruangan pasien berada dikirimkan ke web server yang dapat diakses pada nurse station sehingga akan lebih mudah untuk dipantau perawat. Hasil dari penelitian ini berupa pengukuran volume cairan infus dengan rata-rata error dibawah 2\% (Yayer et al., 2020).

Dan pada Journal of Robotics and Control (JRC) Volume 2 oleh Meilia Safitri, Helena Da Fonseca dan Erika Loniza mengembangkan Sistem yang menyediakan informasi bila kadar cairan infus berada pada 50 $\mathrm{ml}, 20 \mathrm{ml}$, dan 0 melalui SMS. Selain itu, digunakan bel yang bertindak sebagai alarm bila kadarnya mencapai $20 \mathrm{ml}$, dan cairan infus belum ada diganti, dan bila cairan infus tidak menetes. Sensor infra merah dan fotodioda digunakan untuk mendeteksi tetesan cairan intravena, yang kemudian digunakan untuk menghitung volume cairan. Sistem dikendalikan menggunakan Atmega 328 mikrokontroler. Modem SIM 900 digunakan untuk mengirim SMS. Berdasarkan tes yang dilakukan, memiliki sistem pemantauan tingkat cairan infus Kinerja Luar Biasa. Persentase kesalahan sistem saat mendeteksi level cairan infus adalah 1,21\% (Safitri et al., 2021).

Pada penelitian sebelumnya, banyak yang membahas mengenai sistem monitoring cairan infus menggunakan komunikasi pemberat dan web server, namun hal tersebut memiliki keterbatasan pada perlatan yang digunakan masih berbasis komputer dan bersifat stay 
position dan belum mobile. Oleh karena itu penelitian ini akan membahas pengembangan sistem pendeteksi cairan infus menggunakan komunikasi nirkabel Wi-Fi dan mengirimkan notifikasi melalui aplikasi telegram yang dapat diakses oleh siapapun sehingga tidak membatasi pengawas/kerabat dekat pasien.Naskah yang diterima akan ditelaah oleh mitra bestari sesuai kepakarannya, dan penulis harus bersedia melakukan perbaikan atas masukan mitra bestari dan atau penyunting. Program komputer (software) yang digunakan untuk pembuatan maupun editing naskah, atau hal lain yang berkaitan dengan kekayaan intelektual, berikut konsekuensi hukumnya, menjadi tanggung jawab penulis naskah.

\section{METODE}

Pada pembuatan Rancang Bangun Infuse Fluida Detector Untuk Pasien ICU Menggunakan Metode WSN (Wireless Sensor Network) ini, tahapan penelitian yang dilakukan adalah sebagai berikut :

1) Melakukan perancangan sistem yang telah dibuat.

2) Melakukan pemilihan komponen dalam pembuatan alat.

3) Membuat perancangan mekanik, elektrik dan software dalam pembuatan alat.

4) Melakukan pengujian alat dengan program Arduino IDE dan aplikasi telegram pada smartphone.

5) Melakukan analisa dari hasil percobaan.

\section{a. Deskripsi Sistem}

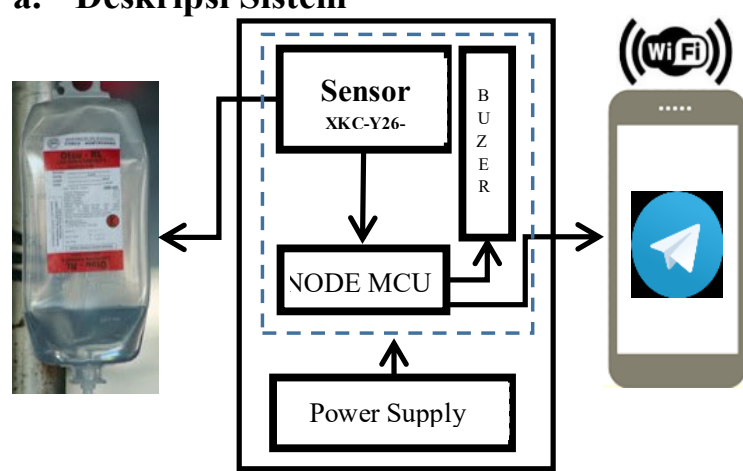

Gambar 1. Blok Diagram Sistem
Pada perangkat detektor atau monitoring cairan infus dengan sensor Liquid Level Switch dengan metode WSN yaitu perangkat yang bertujuan untuk mendeteksi level cairan infus yang diberikan kepada pasien, kemudian mengirimkan pesan secara IoT menuju aplikasi Telegram dan menyalakan LED. Perangkat ini menggunakan NodeMCU ESP8266 sebagai pusat kendali utamanya dan sebagai penghubung dengan internet. Sensor XKCY26-PNP untuk mendeteksi pada saat cairan infus berada pada posisi rendah. Perangkat ini terhubung dengan aplikasi Telegram pada smartphone yang berfungsi sebagai interface untuk mendeteksi cairan pasien dari mana saja melalui koneksi internet. Komponenkomponen yang digunakan pada blok input yaitu sensor XKC-Y26-PNP, proses yaitu menggunakan kontroler NodeMCU dilengkapi modul Wi-Fi ESP8266 serta blok output yaitu Aplikasi Telegram pada smartphone. Sensor Liquid Level akan membaca perubahan level cairan yang kemudian akan diolah oleh NodeMCU untuk mengaktifkan buzzer yang menandakan cairan infus akan habis dan harap segera diganti, kemudian mengirimkan informasi melalui aplikasi Telegram pada smartphone dengan memanfaatkan Modul WiFi ESP8266 yang sudah terintegrasi pada board NodeMCU.

\section{b. Diagram Alir Sistem}

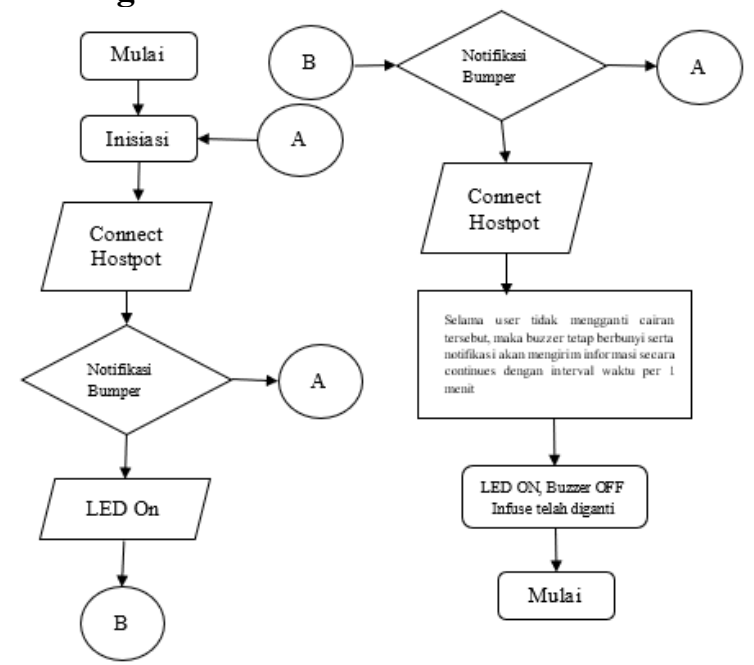

Gambar 2. Diagram Alir Sistem 
Berdasarkan diagram blok sistem pada Gambar 2, tahapan selanjutnya adalah merancang diagram alir atau flowchart sistem yang bertujuan untuk memudahkan proses pembuatan program alat. Gambar 2 . menjelaskan alur dari flowchart sistem yang dimulai pada saat alat menyala, inisialisasi, dan kemudian alat akan membaca dan mengirim pembacaan sensor menuju aplikasi Telegram secara IoT. Pada saat limit level terdeteksi maka alarm berupa LED pada sensor akan menyala notifikasi pesan cairan infus habis akan terkirim.

\section{c. Perancangan Wadah Alat}

Dalam Perancangan alat ini didesain menggunakan gambar 3D sebagai simulasi wadah alat sebelum dibuat secara real. Terlihat pada gambar 3.3 dan 3.4 merupakan desain wadah alat dari tampak samping kanan dan kiri. Adapun di dalam wadah alat ini terdapat beberapa komponen berupa main prosesor, sensor dan komponen daya.

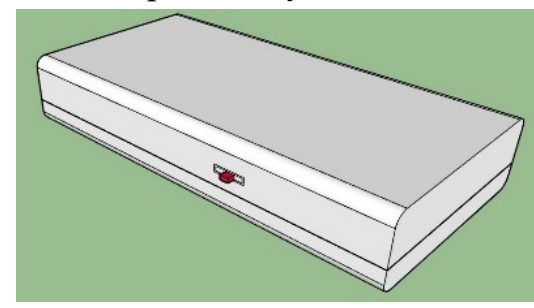

Gambar 3. Desain Alat Tampak Kanan

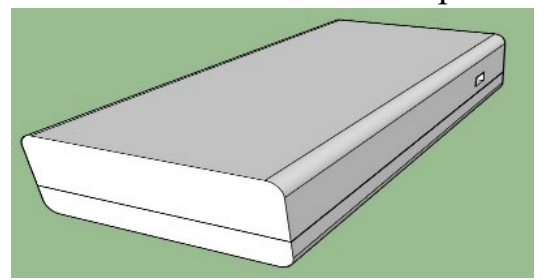

Gambar 4. Desain Alat Tampak Kiri

\section{d. Perancangan Komunikasi Dengan \\ Telegram}

Program ini digunakan untuk terhubung dengan wifi dan juga untuk terhubung dengan aplikasi Telegram pada smartphone dengan memakai token dan id bot yang telah dibuat

\section{HASIL DAN PEMBAHASAN}

\section{a. Implepentasi Wadah Alat}

pada Telegram terlebih dahulu. Dapat dilihat pada gambar 5, 6 dan 7 .

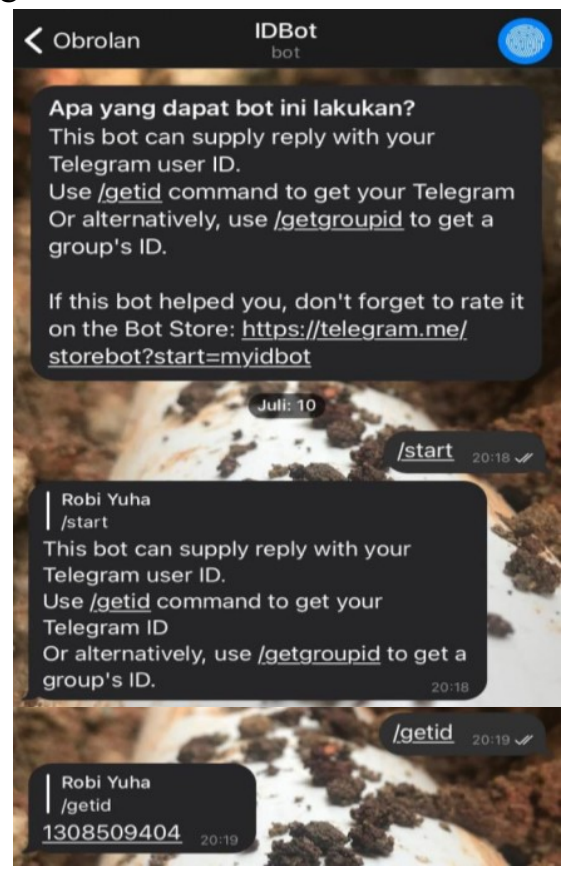

Gambar 5. Pembuatan New Bot Pada Instagram

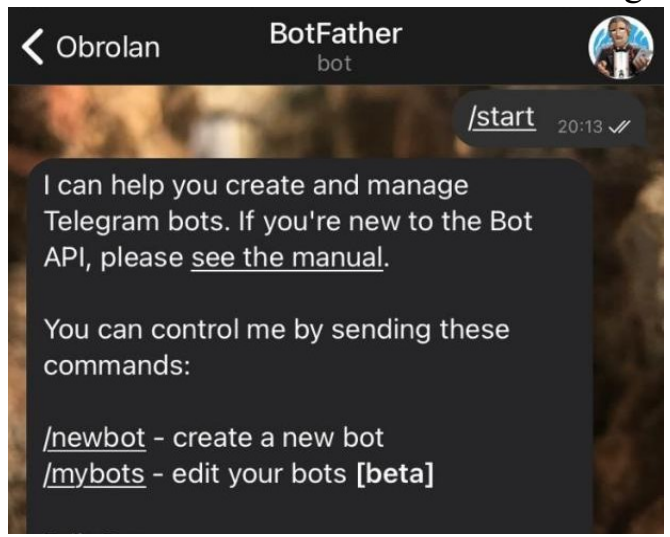

Gambar 6. GetID Bot yang Dibuat

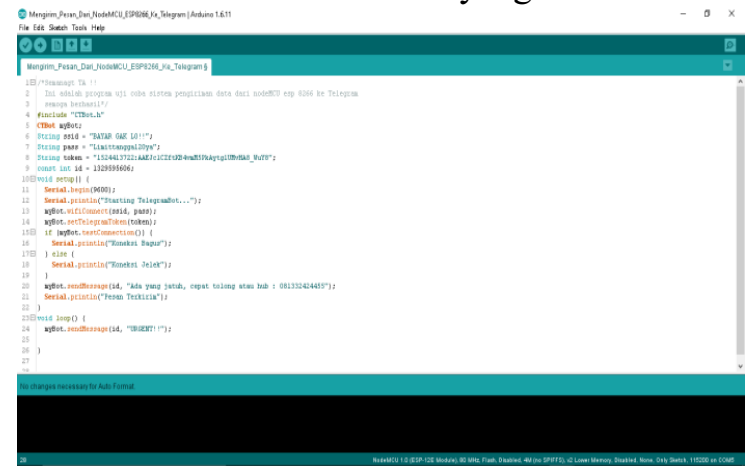

Gambar 7. Program Arduino IDE

Perancangan perangkat keras dimana keseluruhan alat memiliki volume bangun 
panjang $14 \mathrm{~cm}$, lebar $6 \mathrm{~cm}$ dan tinggi $2 \mathrm{~cm}$ dengan tampilan seperti pada Gambar 8 .

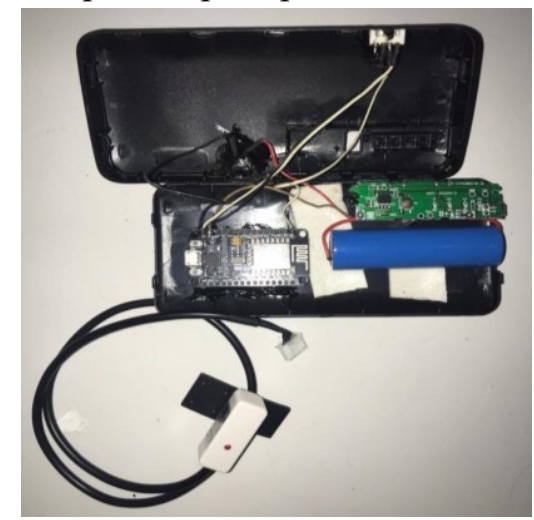

Gambar 8. Tampilan Perangkat Keras

\section{b. Implementasi Komunikasi Dengan Telegram}

Hasil dari perancangan perangkat lunak yang berupa tampilan pada aplikasi Telegram. Dapat dilihat pada Gambar 12. Interface aplikasi Telegram dengan Bot yang sudah dibuat sebelumnya. Terlihat pada gambar 9 .

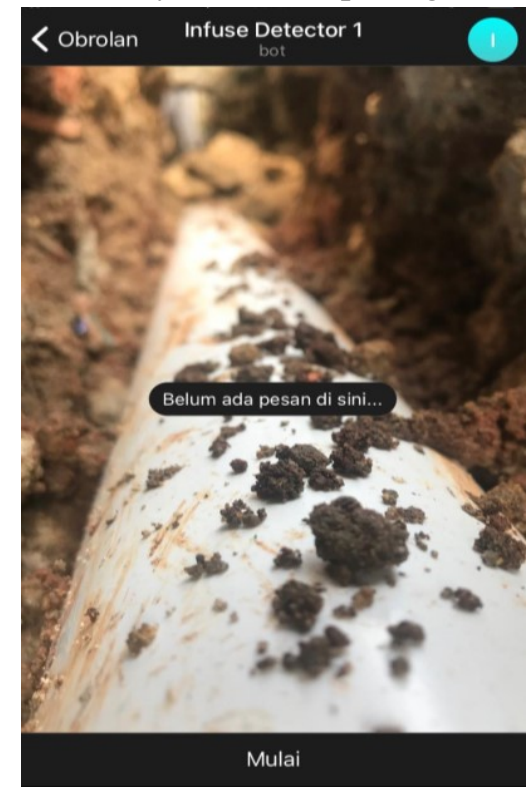

Gambar 9 Tampilan Aplikasi Bot Telegram

\section{c. Pengujian Sistem}

Pengujian yang dilakukan untuk melihat hasil implementasi dari perancangan sistem. Adapun beberapa sistem penting yang dilakukan pengujian, antara lain pengujian kecepatan pengiriman data, pengujian aktivitas jatuh pasien dan kecepatan pengiriman notifikasi.
Tabel 1 Pengujian Voltage Cairan Terdeteksi

\begin{tabular}{cc}
\hline Uji Coba & Voltage \\
\hline 1 & 5,0 \\
2 & 5,1 \\
3 & 5,0 \\
4 & 5,0 \\
5 & 5,0 \\
6 & 5,2 \\
7 & 5,0 \\
8 & 5,0 \\
9 & 5,1 \\
10 & 1,1 \\
\hline
\end{tabular}

Pengujian ini bertujuan untuk melihat seberapa besaran voltase pada saat sensor cairan terdeteksi yang menggunakan multimeter digital. Hasil pengujian ini dimasukkan kedalam Tabel 1. yang berisi 10 pengujian nilai data voltase dalam satuan volt (V). Dapat disimpulkan bahwa nilai rata-rata tegangan pada saat cairan terdeteksi adalah $5 \mathrm{~V}$. Sedangkan pada saat sensor mendeteksi cairan kosong maka voltase bernilai $0 \mathrm{~V}$.

Tabel 2 Pengujian Kecepatan Pengiriman Data

\begin{tabular}{ccc}
\hline Uji Coba & Kecepatan (s) & Hasil \\
\hline 1 & 1,0 & OK \\
2 & 1,0 & OK \\
3 & 1,0 & OK \\
4 & 0,9 & OK \\
5 & 1,0 & OK \\
6 & 1,1 & OK \\
7 & 1,0 & OK \\
8 & 1,0 & OK \\
9 & 0,9 & OK \\
10 & 1,0 & OK \\
\hline
\end{tabular}

Pengujian ini bertujuan untuk melihat seberapa cepat pengiriman dan keakuratan data dari NodeMCU menuju Telegram melalui jaringan internet dengan menggunakan WiFi pada smartphone setelah data di terima dan di proses oleh NodeMCU. Hasil pengujian ini dimasukkan ke dalam Tabel 2. yang berisi 10 pengujian nilai kecepatan pengiriman data dalam satuan detik dan akurasi nilai data. Dapat 
disimpulkan rata-rata kecepatan pengiriman data yaitu 1,0 detik.

Tabel 3 Pengujian Aktivitas Pasien Tidur

\begin{tabular}{|c|c|c|c|c|}
\hline $\begin{array}{c}\text { Uji } \\
\text { Coba }\end{array}$ & $\begin{array}{c}\text { Posisi } \\
\text { Sensor/ml }\end{array}$ & $\begin{array}{l}\text { Kecepatan } \\
\text { (s) }\end{array}$ & Indikator & Hasil \\
\hline 1 & 100 & 0,2 & Buzzer & $\begin{array}{c}\text { Cairan } \\
\text { Kosong }\end{array}$ \\
\hline 2 & 100 & 0,2 & Buzzer & $\begin{array}{c}\text { Cairan } \\
\text { Kosong }\end{array}$ \\
\hline 3 & 100 & 0,2 & Buzzer & $\begin{array}{l}\text { Cairan } \\
\text { Kosong }\end{array}$ \\
\hline 4 & 100 & 0,2 & Buzzer & $\begin{array}{l}\text { Cairan } \\
\text { Kosong }\end{array}$ \\
\hline 5 & 100 & 0,2 & Buzzer & $\begin{array}{l}\text { Cairan } \\
\text { Kosong }\end{array}$ \\
\hline 6 & 100 & 0,2 & Buzzer & $\begin{array}{l}\text { Cairan } \\
\text { Kosong }\end{array}$ \\
\hline 7 & 100 & 0,2 & Buzzer & $\begin{array}{c}\text { Cairan } \\
\text { Kosong }\end{array}$ \\
\hline 8 & 100 & 0,2 & Buzzer & $\begin{array}{l}\text { Cairan } \\
\text { Kosong }\end{array}$ \\
\hline 9 & 100 & 0,2 & Buzzer & $\begin{array}{c}\text { Cairan } \\
\text { Kosong }\end{array}$ \\
\hline 10 & 100 & 0,2 & Buzzer & $\begin{array}{c}\text { Cairan } \\
\text { Kosong }\end{array}$ \\
\hline
\end{tabular}

Tabel 4 Pengujian Aktivitas Pasien Berjalan

\begin{tabular}{|c|c|c|c|c|}
\hline $\begin{array}{c}\text { Uji } \\
\text { Coba }\end{array}$ & $\begin{array}{c}\text { Posisi } \\
\text { Sensor/ml } \\
\end{array}$ & $\begin{array}{c}\text { Kecepatan } \\
\text { (s) }\end{array}$ & Indikator & Hasil \\
\hline 1 & 50 & 0,2 & Buzzer & $\begin{array}{c}\text { Cairan } \\
\text { Kosong }\end{array}$ \\
\hline 2 & 50 & 0,2 & Buzzer & $\begin{array}{c}\text { Cairan } \\
\text { Kosong }\end{array}$ \\
\hline 3 & 50 & 0,2 & Buzzer & $\begin{array}{c}\text { Cairan } \\
\text { Kosong }\end{array}$ \\
\hline 4 & 50 & 0,2 & Buzzer & $\begin{array}{l}\text { Cairan } \\
\text { Kosong }\end{array}$ \\
\hline 5 & 50 & 0,2 & Buzzer & $\begin{array}{c}\text { Cairan } \\
\text { Kosong }\end{array}$ \\
\hline 6 & 50 & 0,2 & Buzzer & $\begin{array}{l}\text { Cairan } \\
\text { Kosong }\end{array}$ \\
\hline 7 & 50 & 0,2 & Buzzer & $\begin{array}{c}\text { Cairan } \\
\text { Kosong }\end{array}$ \\
\hline 8 & 50 & 0,2 & Buzzer & $\begin{array}{l}\text { Cairan } \\
\text { Kosong }\end{array}$ \\
\hline 9 & 50 & 0,2 & Buzzer & $\begin{array}{l}\text { Cairan } \\
\text { Kosong }\end{array}$ \\
\hline 10 & 50 & 0,2 & Buzzer & $\begin{array}{l}\text { Cairan } \\
\text { Kosong }\end{array}$ \\
\hline
\end{tabular}

Pengujian ini dilakukan untuk menguji fungsi dan kecepatan pengiriman data ke Telegram saat sensor mendeteksi tidak adanya cairan infus. Hasil pengujian ini dimasukkan ke dalam Tabel 3 dan Tabel 4. yang berisi 10 pengujian dengan kolom waktu dan hasil.
Pengujian ini bertujuan untuk melihat aktivitas yang dilakukan oleh sensor XKC-Y26-PNP. dapat disimpulkan, sensor yang ditempatkan pada 2 posisi $100 \mathrm{ml}$ dan $50 \mathrm{ml}$, mendapatkan hasil delay 0,2 detik.

\section{d. Tampilan Notifikasi Yang Masuk Ke Telegram \\ Bot pada Telegram ini di rancang dapat} menerima notifikasi yaitu "Cairan Infuse 1 Akan Habis, Harap Segera Diganti.!!!" dan diulangi dengan interval waktu per 1 menit yang muncul terus menerus sampai sensor kembali mendeteksi adanya cairan. Dapat dilihat pada gambar 10 .

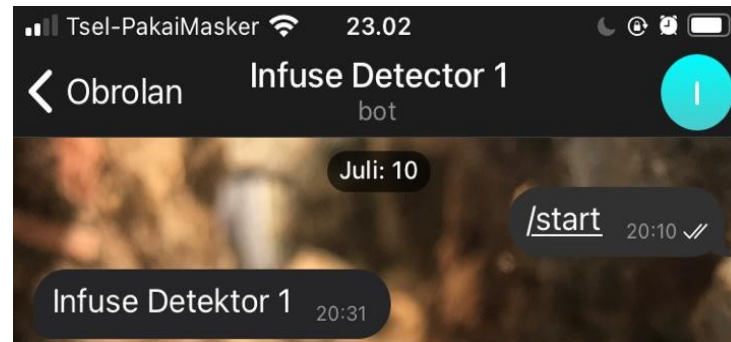

Cairan Infuse 1 Akan Habis, Harap Segera

Diganti.!!!

Cairan Infuse 1 Akan Habis, Harap Segera Diganti.!!!

Cairan Infuse 1 Akan Habis, Harap Segera Diganti.!!!

Cairan Infuse 1 Akan Habis, Harap Segera Diganti.!!!

Gambar 10. Tampilan Notifikasi Pada Telegram

\section{SIMPULAN}

Setelah proses penelitian Rancang Bangun Infuse Detector Fluida Untuk Pasien ICU menggunakan Metode Wirelss Sensor Network (WSN) yang berisikan perancangan, implementasi, pengujian dan analisa maka dapat disimpulkan:

1. Perangkat ini dapat mendeteksi cairan infus pasien pada saat botol infus akan habis atau tidak terdeteksi adanya cairan.

2. Percobaan ini dilakukan dengan menempatkan sensor pada 2 posisi dan 
menghasilkan delay rerata yaitu 0,2 detik pada prosesnya.

3. Pada saat sensor mendeteksi tidak adanya cairan, maka buzer akan berbunyi serta mengirimkan notifikasi pada Bot Telegram yang sudah dibuat dan bersifat terus menerus sampai sensor kembali mendeteksi cairan pada botol infus.

\section{DAFTAR RUJUKAN}

Firdaus, M. Y., al Banna, A. S., \& Saputra, A. T. (2020). SISTEM KONTROL DAN MONITORING INFUS BERBASIS NODEMCU. Prosiding Seminar Nasional Terapan Riset Inovatif (SENTRINOV), 6(1), 372-378.

Hammad, H., Rizani, K., \& Agisti, R. (2018). TINGKAT KELELAHAN PERAWAT DI RUANG ICU. Dunia Keperawatan, 6(1). https://doi.org/10.20527/dk.v6i1.4957
Safitri, M., da Fonseca, H., \& Loniza, E. (2021). Short Text Message Based Infusion Fluid Level Monitoring System. Journal of Robotics and Control (JRC), $2(2), 60-64$.

Widiawati, S., Apriana, O., \& Merdekawati, D. (2017). Hubungan supervisi dan motivasi dengan pemberian cairan infus sesuai SPO oleh perawat pelaksana. Jurnal Endurance: Kajian Ilmiah Problema Kesehatan, 2(3), 280-284.

Yayer, K. N. T., Weliamto, W. A., Sitepu, R., \& Pranjoto, H. (2020). MONITORING DAN PENGHENTIAN CAIRAN INFUS MENGGUNAKAN TIMBANGAN INFUS DIGITAL DENGAN MEMANFAATKAN WEB SERVER. Simetris: Jurnal Teknik Mesin, Elektro Dan Ilmu Komputer, 11(1), 55-64. 